\title{
Forest bioeconomy in Ontario - A policy discussion
}

\author{
by I. Majumdar ${ }^{1, *}$, K.A. Campbell, J. Maure, I. Saleem, J. Halasz and J. Mutton
}

\begin{abstract}
Ontario's forest sector has been undergoing a significant structural shift resulting from a more than decade-long trend of declining markets for traditional products. Though there have been signs of industry recovery, the forestry industry is still far smaller than it once was. In order to sustain and improve Ontario's economic position, we must develop policies and supporting programs that transition our forest economy to a more robust and diverse set of markets, including capitalizing on opportunities that come from a thriving and sustainable forest bioeconomy. The current suite of programs is fragmented and does not provide support for all types of bioproducts and policy initiatives, nor across all sections of the value chain. These factors, coupled with the lack of a clear strategic direction for the bioeconomy, have contributed to Ontario's slow emergence into the bioeconomy when compared to other jurisdictions. It is proposed that a key way to improve the effectiveness and efficiency of policy support for the emerging bioeconomy is to integrate and coordinate the actions of the government with industry and academia players involved in the bioproducts sector. Forest policy needs to take a balanced, integrated approach to promote all aspects of the bioeconomy to help ensure the eventual success of Ontario's forest bioeconomy.
\end{abstract}

Keywords: forest policy, forest biofibre, forest biomass, forest bioeconomy, bioenergy, bioproduct, value chain, Ontario.

\section{RÉSUMÉ}

Le secteur forestier de l'Ontario a connu un changement structurel important découlant d'une diminution systématique des marchés pour les produits traditionnels sur plus de dix ans. Même si le secteur a démontré des signes de reprise, l'industrie forestière n’a plus l'importance quelle avait avant. Pour maintenir, voire accroître la situation économique de l'Ontario, il faudra élaborer des politiques et des programmes d’aide qui feront passer notre économie forestière à des marchés plus dynamiques et plus diversifiés, notamment en saisissant les opportunités quoffre la bioéconomie forestière, un secteur durable et en plein essor. L'ensemble des programmes actuels est décousu et n’apporte pas l'appui nécessaire aux les divers types de bioproduits et ni aux initiatives stratégiques, pas plus quà l'ensemble des éléments de la chaîne de valeur. Ces facteurs, combinés à l'absence d’orientations stratégiques précises, ont contribué à ralentir lentrée de l'Ontario dans la bioéconomie, comparativement à d’autres provinces. Il nous semble que la clé pour accroître l'efficacité et l'efficience de laide stratégique à promouvoir la bioéconomie repose sur une action concertée du gouvernement et des acteurs industriels et universitaires œuvrant dans le secteur des bioproduits. Il faudra des politiques forestières équilibrée et intégrée pour promouvoir l'ensemble des composantes de la bioéconomie et ainsi assurer le succès de la bioéconomie forestière en Ontario.

Mots clés : politique forestière, biofibre forestière, biomasse forestière, bioéconomie forestière, bioénergie, bioproduit, chaîne de valeur, Ontario

\section{Introduction}

Ontario's forest industries, and the associated dependent rural and northern communities, have been experiencing immense economic and social disruption for over a decade. The disruption is based on a variety of external variables, including the global economic downturn and financial crisis in 2007 and 2008, and the associated reduction in global market demand for traditional forest products. The traditional forest sector in Canada saw a loss of $40 \%$ in direct employment from 2004 to 2013. Over the same period, Ontario's direct forest sector employment witnessed an even more drastic decrease of $53 \% .^{2}$ This shift is further exacerbated by global economic trends and fluctuations in energy prices and the value of the Canadian dollar. According to the Forest Products Association of Canada Vision 2020 (FPAC 2012), the Canadian forest industry needs to "find ways to generate an additional $\$ 20$ billion in economic activity from new innovations and new markets by 2020". By utilizing these novel innovations and participating in new markets, the forest industry will transform into an active participant in the bioeconomy.

\footnotetext{
${ }^{2}$ http://cfs.nrcan.gc.ca/statsprofile/overview/on
}

\footnotetext{
${ }^{1}$ Ontario Ministry of Natural Resources and Forestry, 70 Foster Drive, Suite 210, Sault Ste. Marie, ON P6A 6V5

*corresponding author: indrajit.majumdar@ontario.ca
} 
The Ontario forest industry is changing in response to these market factors. It is shifting from using mainly the bole of harvested trees towards using all above-ground parts of the tree including slash, bark, pulping liquor, wood shavings and sawdust (Puddister et al. 2011). Improved utilization of trees provides an opportunity to add value to the traditional lumber and pulp and paper industries and to develop the forestbased bioeconomy. This means that bioenergy (fuels, heat and electricity), biochemicals and biomaterials can be created from parts of trees that have been traditionally left behind as residues, burned in slash piles, or landfilled.

International climate change strategies have been an important policy driver of bioeconomy-related industries. Many jurisdictions around the world, including those in North America, have already established or are in the process of developing greenhouse gas (GHG) emission reduction programs. The development of new forest bioproducts has often been supported and driven by policies and programs that resulted from climate change strategies because forestbased products are seen as sustainable and renewable, and can be green substitutes for conventional fossil fuel products. For example, under Ontario's Five-Year Climate Change Action Plan (2016-2020), the province is mandated to develop a Renewable Fuel Standard aimed at increasing the use and availability of lower-carbon fuels by creating incentives for gasoline suppliers. As more jurisdictions implement climate change mitigation strategies, and implement carbon pricing, it is clear that markets for these bioproducts are international and growing.

Bioproduct sectors around the world are forecasted to expand over the next few years. BCC Research estimates that the global demand for bioproducts will increase at a double-digit compound annual growth rate (CAGR) of $12.6 \%$ over the next three years to reach $\$ 700.7$ billion in 2018 up from \$387.6 billion in 2013 (Gobina 2014). By 2020, it is estimated that the annual global demand for tree-based bioproducts will reach US $\$ 200$ billion (FPAC 2011). Compared to the global growth rate of the bioproducts industry, Canada witnessed a declining trend for the period 2003-2009, although Ontario's bioeconomy grew from 53 to 68 firms over the same period of time (Sparling et al. 2011). But given the extent of Canada's forest resources with the estimated volume of available unutilized forest biofibre (Dymond et al. 2010, Levin et al. 2011, Puddister et al. 2011) and an existing strong manufacturing base in Ontario, the overall declining trend appears to be counterintuitive. Ontario's bioeconomy is not as competitive as other jurisdictions. The most competitive jurisdictions are those whose governments increase productivity by foster- ing innovation, all else being constant (PwC 2011). Thus, policies and programs are a key tool for governments to improve the competitiveness of their jurisdiction (Porter 1990). As a nascent industry, the production and consumption of bioenergy are highly dependent on government policies, and so, in part, Ontario's bioeconomy is not as competitive because of the current policy suite (Sorda et al. 2010).

In this analysis, the policies influencing the development of the forest bioeconomy in Ontario are assessed by a classification system and through comparisons to leading jurisdictions. Fig. 1 is a visual representation of the methodology employed and also shows how the associated appendices feed into the discussion. The focus of this paper is on the critical role of government policies in supporting the forest bioeconomy. Specifically, we address two central questions: (1) How robust is the distribution of Ontario's policies and programs that are relevant to the development of the forest bioeconomy? (2) What types of policies and programs are utilized by international jurisdictions to foster a viable and competitive bioeconomy that could provide a gold standard of success for Ontario's policymakers to follow?

\section{Forest bioeconomy and bioproducts}

Bioproducts are defined as consumer or industrial products that are derived in whole, or in significant part, from biomass.

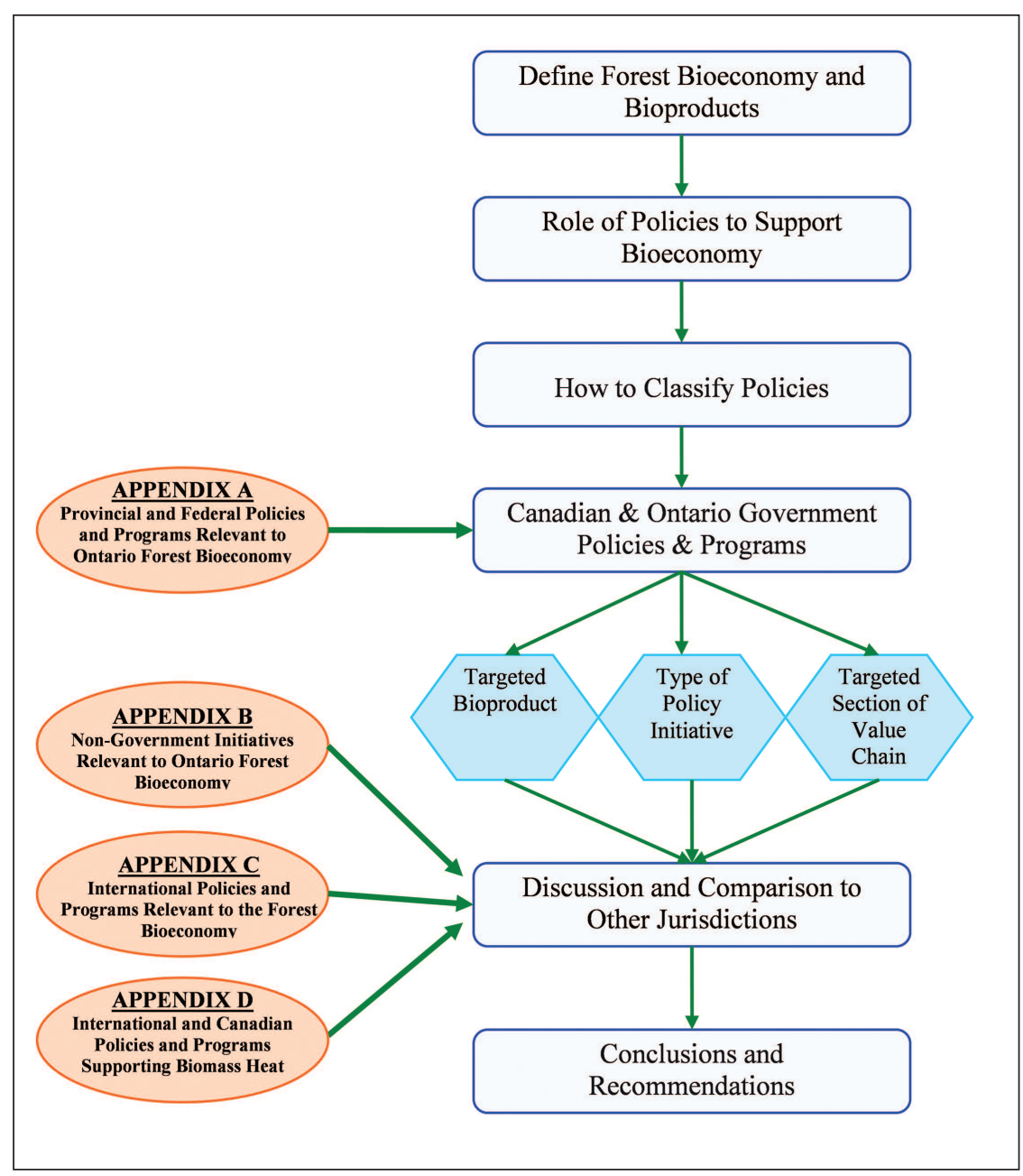

Fig. 1. Flow chart of methodology 
Table 1: Biomass derived bioproducts

\begin{tabular}{|c|c|c|c|}
\hline \multicolumn{2}{|l|}{ Bioproduct Group } & \multirow{2}{*}{$\begin{array}{l}\text { Potential \& Established Bioproducts }{ }^{1} \\
\text { - Basic and specialty chemicals (e.g., Succinic acid, } \\
\text { Levulinic acid, Polylactic acid and Ligno } \\
\text { sulphate/sulphonate) } \\
\text { - Resins, paints, lubricants and solvents } \\
\text { - Biopharmaceuticals } \\
\text { - Nutraceuticals } \\
\text { - Pest control agents }\end{array}$} & \multirow{2}{*}{$\begin{array}{l}\text { Ontario Business }^{2} \\
\text { Northway Lignin Chemical, Vertichem } \\
\text { Corporation, BioAmber, GreenField } \\
\text { Specialty Alcohols, G2 BioChem }\end{array}$} \\
\hline Biochemicals & & & \\
\hline Biomaterials & & $\begin{array}{l}\text { - Bioplastics } \\
\text { - Biofibres (e.g., viscose fibre, carbon black, } \\
\text { nanocrystalline cellulose) } \\
\text { - Biocomposites } \\
\text { - Engineered wood products } \\
\text { (e.g., cross-laminated timber) }\end{array}$ & $\begin{array}{l}\text { - GreenCore Composites, The } \\
\text { Woodbridge Group, Valle Foam } \\
\text { Industries, MAGNA Interiors and } \\
\text { Exteriors }\end{array}$ \\
\hline \multirow[t]{4}{*}{ Bioenergy } & Fuel & $\begin{array}{l}\text { - Liquid and gas fuels (e.g., bio-dimethyl ether, } \\
\text { ethanol, pyrolysis/bio-oil, biogas/syngas) }\end{array}$ & $\begin{array}{l}\text { - Ensyn Technologies Inc., Woodland } \\
\text { Biofuels, Greenfield Ethanol, Iogen } \\
\text { Corporation, Elementa Group }\end{array}$ \\
\hline & Heat & $\begin{array}{l}\text { - Solid biomass for combustion or gasification to } \\
\text { generate heat } \\
\text { - Wood pellets for residential or institutional heat } \\
\text { - Most existing sawmills in Ontario produce heat for } \\
\text { internal use using forest biomass }\end{array}$ & $\begin{array}{l}\text { KD Quality Pellets, Resolute Forest } \\
\text { Products, Rentech Inc. }\end{array}$ \\
\hline & Electricity & $\begin{array}{l}\text { Solid biomass for combustion or gasification to } \\
\text { generate electricity (includes co-firing with coal) }\end{array}$ & $\begin{array}{l}\text { Atikokan Generating Station, Calstock } \\
\text { Power Plant, Kirkland Lake Generating } \\
\text { Station }\end{array}$ \\
\hline & $\begin{array}{l}\text { Combined Heat } \\
\text { and Power } \\
(\mathrm{CHP})\end{array}$ & $\begin{array}{l}\text { - Most existing pulp mills in Ontario currently produce } \\
\text { heat and power for internal use using forest biomass }\end{array}$ & $\begin{array}{l}\text { - Resolute Forest Products, Tembec Inc., } \\
\text { Domtar Inc., Becker Cogeneration Plant }\end{array}$ \\
\hline
\end{tabular}

${ }^{1}$ Traditional wood products are also produced from forest biomass, but they are not highlighted here.

${ }^{2}$ Some of these businesses are currently using agricultural feedstocks.

Biomass refers to biological or renewable materials made from any organic material (plants or animals), and is generally categorized by its source: agricultural (e.g., corn, animal processing waste, manure), forest (e.g., whole trees, bark, tops and branches, wood chips, sawdust) and post-consumer waste (e.g., municipal solid waste, demolition/construction materials, compost, used cooking oils). Typically, forest bioproducts are divided into three main categories: biochemicals, biomaterials and bioenergy. Table 1 demonstrates types of bioproducts that are currently known or are projected to be derived from biomass. It also identifies some examples of Ontario businesses that produce these types of bioproducts.

Expanding production of bioproducts will support the traditional forest industry by allowing the costs for planning, road construction and maintenance, harvesting and silvicultural activities to be distributed across multiple products and their respective value chains. The forest bioeconomy is, however, not solely limited to bioproducts. There are many aspects associated with the production of bioproducts that are also important aspects elsewhere in the economy, including technology, services, infrastructure, construction, transportation, research and development. As a result, the growth of the bioeconomy will produce social and economic benefits throughout many other sectors across Ontario (OECD 2009, Puddister et. al. 2011).

\section{Role of public policies to support the bioeconomy}

Similar to other industrial or non-industrial sectors, public policies are a key government tool to promote the emergence, growth, and sustainability of the forest-based bioproduct sector. Governments that prioritize the forest bioeconomy have made significant progress by developing policies geared towards encouraging research and development (R\&D) and the production of bioproducts (see Appendix C and D). Policy support plays a significant role in increasing the competitiveness of a sector in its infancy stage, and without any government intervention, bioproducts have a significantly higher cost than conventional fossil-fuel-based competitor products (Cooke 2007, OECD 2009, Cockburn and Stern 2010, PwC 2011). Therefore, public policies are necessary to support the emerging bioproduct sector. For example, Sweden, which has a large forest area (53\% of its landmass) and a well-established network of district heating, relies on policy support to guide the development of its bioenergy sector (Cooper 2007). As a result of its policy mix, Sweden has emerged as a world leader in the bioeconomy, particularly bioenergy use: $30 \%$ of the national energy supply comes from biomass, and $85 \%$ of that biomass is forest-based. In comparison, only $1 \%$ of energy in Ontario is generated by biomass.

Since the bioproduct sector competes with conventional products and fossil fuel-based energy sectors for its end prod- 
ucts, it is important that governments prioritize policies that will make the bioproduct sector sufficiently competitive (Kant and Wang 2012). Government mandated strategies in the US and EU have set out commitments for establishing a competitive bioeconomy. In 2012, the European Commission adopted a strategy, "Innovating for Sustainable Growth: a Bioeconomy for Europe" that highlighted environment, food and energy security and increasing Europe's competitiveness for the future as important drivers for bioeconomy development (European Commission 2012). Within the EU, Sweden in 2012 (Swedish Research and Innovation Strategy for a Biobased Economy) and Finland in 2014 (The Finnish Bioeconomy Strategy) both established comprehensive national strategies to foster a competitive bioeconomy. In Canada, no such strategy exists, and although efforts have been made to set generalized roadmaps for development of markets for biomass resources as a whole, no comprehensive strategies have been established, either federal or provincially, to support the expansion of the forest bioeconomy.

\section{Classification of policy instruments}

To support the policy discussions and to help quantify policy instrument distribution, a classification system was utilized. Provincial and federal policies and programs that are relevant to the development of the forest bioeconomy in Ontario were identified and summarized in Appendix A.

Policies were first categorized by the type of bioproducts that the individual policies targeted: renewable energy (fuel, heat and electricity) versus biochemicals and biomaterials. It is important to note that some policies and programs are not restricted to bioproducts. Since many policies are specific to just biofuels or renewable electricity production, bioenergy was identified separately while the higher valued biochemicals and biomaterials were combined into one category.

Another method employed for classification was to categorize by the type of policy initiative (Pembina Institute 2005, Becker et al. 2009, Becker et al. 2011). The policy initiative categories that were considered for this review were modified from a Pembina Institute study produced in 2005, and were based on the degree of influence involved in regulations, economic incentives/disincentives, and information (Pembina Institute 2005). The specific categories included:

- Financial incentives (e.g., grants, tax credits and exemptions, loans, accelerated capital cost allowances);

- Research support (e.g., academic centres and chairs, awards, grants);

- Information programs (e.g., awareness and education);

- Procurement, demonstration and pilot programs; and,

- Regulations, standards and guidelines (e.g., purchasing targets, blended fuel requirements, cap and trade, carbon $\operatorname{tax})$.

Finally, each policy and program was categorized by the targeted section of the value chain. The bioproduct value chain is complex and requires significant interaction and linkage between, in some cases, disparate groups along the value chain. Providing value to consumers depends on coordination and partnership across the value chain which consists of both production and consumption activities. Production activities can be further broken down into: upstream (feedstock, energy, and other inputs), manufacturing (labour, capital, land), and delivery (storage and distribution). Policies and programs are often directed at a single stage of the value chain. Utilizing a framework that classifies policies by value chain helps identify gaps in policy design (Becker et al. 2011). Fig. 2 represents the framework used to categorize the point in the value chain where government actions and policies are focused.

\section{Canadian and Ontario government policies and pro- grams}

This paper is focused on federal and provincial government policies and programs related to bioproducts from forest biomass in Ontario. For reference, appendices are hosted online: Appendix A lists and describes the most relevant federal and

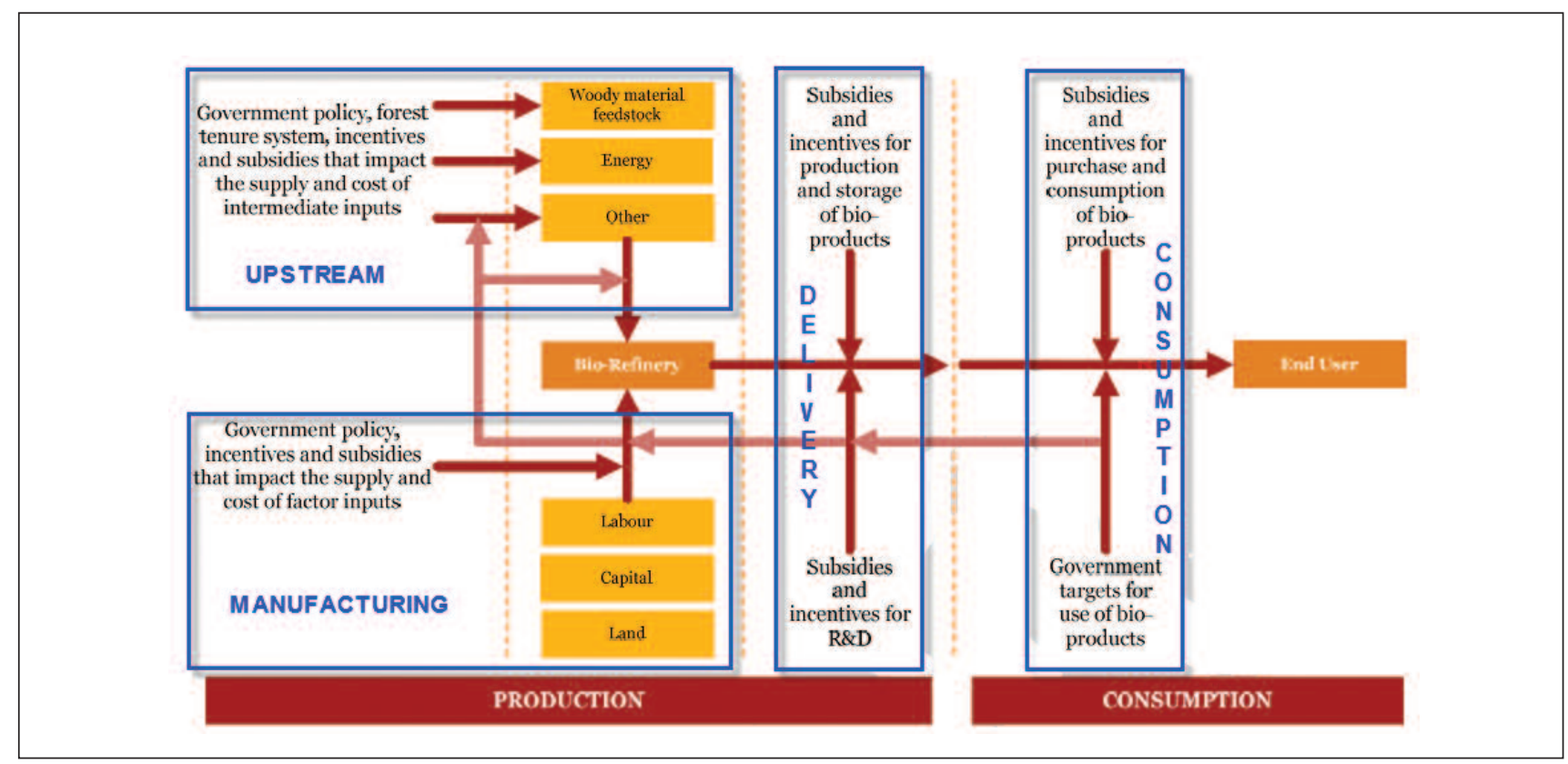

Fig. 2. Value Chain Framework (modified version of PwC 2011) 
provincial policies; Appendix B contains non-governmental initiatives related to the forest bioeconomy, including academic centres, not-for-profit organizations, and industry member organizations; for comparison, international jurisdictions' policies and programs are listed in Appendix C; and Appendix D outlines international and Canadian policies and programs supporting biomass heat.

Tables 2 and 3 list Ontario's and Canada's prominent policies and programs respectively, categorized by targeted bioproduct, type of policy initiative, and targeted section of the value chain. Some obsolete and fully-subscribed programs are included to give a wider picture of the scope of existing and extinct policies and programs. Readers will note that bioeconomy policies are relevant to the mandates of a number of $\mathrm{min}$ istries and agencies, as evidenced from the distribution of multiple ministries responsible for implementing the programs and policies (see also: Appendix A). It is clear that there is a need to continue to coordinate among ministries involved in supporting the bioeconomy so that their resources and program activities are better aligned for effective outcomes.

\section{Discussion}

This analysis will proceed with a discussion about the patterns and trends in the policies and programs of Canada and Ontario, and remark upon room for growth in the development of the Canadian and Ontario bioeconomy. By comparing Ontario to Northern Europe, a region with a mature bioeconomy, we will provide context and show that Ontario still has far to go before its bioeconomy can compete with other jurisdictions. A detailed comparison of federal and provincial policy linkages are beyond the scope for this paper, and could be the subject of future assessments. This section is divided into three specific discussions: (1) policy support for targeted bioproducts; (2) the types of policy initiatives employed; and, (3) policies targeted to a specific section of the value chain.

\section{Bioproduct type}

As in most jurisdictions, the majority of policies and programs in Ontario and Canada (from Tables 2 and 3) that are specific to a type of bioproduct are directed to support the development of renewable energy, which includes the bioenergy sector (Hermann et al. 2011). Despite having a relatively underdeveloped bioenergy sector when compared with the EU and the US, several initiatives in Canada and Ontario have been implemented to specifically promote bioenergy production. For example, the Province of Ontario has multiple linked policies and programs targeted at renewable electricity production. The Ontario Power Authority's Feed-inTariff (FIT) and MicroFIT programs have successfully supported renewable wind and solar projects but have not resulted in many forest biomass projects; instead, they support mostly farm biogas initiatives. More recently, the launch of the Large Renewable Procurement (LRP) program indicated a further shift towards investment in large renewables infrastructure, however, it is worth noting that out of the 16 successful LRP proponents, there were no contracts awarded for forest-based bioenergy projects. ${ }^{3}$

\footnotetext{
${ }^{3}$ http://www.ieso.ca/Documents/generation-procurement/lrp/lrp1-final/LRP-I-RFP-Selected-Proponents-List.pdf
}

In addition, Ontario phased out coal-fired power generation in 2014, which resulted in two coal generating stations being converted to wood pellet generation. The province's emphasis on clean and renewable energy was reinforced by the 2013 Long-Term Energy Plan, which set out an energy roadmap to bring clean, cost-effective, and sustainable energy to consumers. Though there is no bioenergy-specific target included in the plan, the province aims to have $10700 \mathrm{MW}$ of wind, solar and bioenergy online by 2021 .

Production of biofuels is characterized by low margins and bulk scale. The role of government regulations and taxation supporting the rapid growth of the biofuels industry across jurisdictions has been significant because, without the support, biofuel production would not be cost competitive (IISD 2012). Examples of supporting policies for the production of biofuels in Europe include regulations like the Renewable Energy Sources Act in Germany, which guarantees tariffs for producers of renewable energy to ensure greater price competitiveness of bioenergy and other renewable energy (Bug 2010, Nast 2010). The Swedish Energy Tax Act focuses on the taxation of fossil fuels, and increases the production of biofuels by creating less price discrepancy between conventional fuels and biofuels. Carbon/energy taxation in Finland also plays a similar role. In the Canadian context, Ontario, Quebec and British Columbia have implemented tax-based programs which provide tax exemptions for renewably produced transport fuels.

Ontario is a Canadian leader in the development of biofuels. This can be demonstrated by the various policies in place to support the biofuels industry, but also by the provincial government's decision in April 2014 to repeal the tax exemption for biodiesel fuels previously provided under the Fuel Tax Act that was established in 2002. Ontario has also mandated specified biodiesel/renewable diesel content requirements and GHG reduction standards. ${ }^{4}$ The Ontario Regulation 535/05: Ethanol in Gasoline was implemented in 2005 and requires 5\% ethanol in gas. Ontario's Ethanol Growth Fund was introduced in 2005 but was fully subscribed with first generation projects sourced from agricultural feedstock as opposed to cellulosic feedstock. As such, biofuel policies have had a limited impact for the forest industry in Ontario. In comparison, Quebec's policy support for ethanol has utilized similar policy tools as Ontario's Ethanol Growth Fund but they have targeted cellulosic ethanol made from wood feedstock. Quebec's policy support started with R\&D (2006-2012 Climate Change Action Plan), expanded to include a 2011 Cellulosic Ethanol Production Tax Credit, and provided a grant to support the construction of a full-scale commercial cellulosic ethanol plant.

Heat is a large component of our province's energy use. In 2012 , heat accounted for approximately $85 \%$ of total residential energy use and $54 \%$ of total commercial/institutional energy use (OEE 2014a, 2014b). Many studies have found that biomass heat is a considerably less expensive GHG-offset strategy when compared to similar transitions for transportation fuels like ethanol (Samson et al. 2008). It can also reduce fuel costs to consumers and create local employment

\footnotetext{
${ }^{4}$ http://www.ebr.gov.on.ca/ERS-WEB-External/displaynoticecontent.
} do? noticeId=MTIwOTA2\&statusId=MTgyODMx\&language $=$ en 


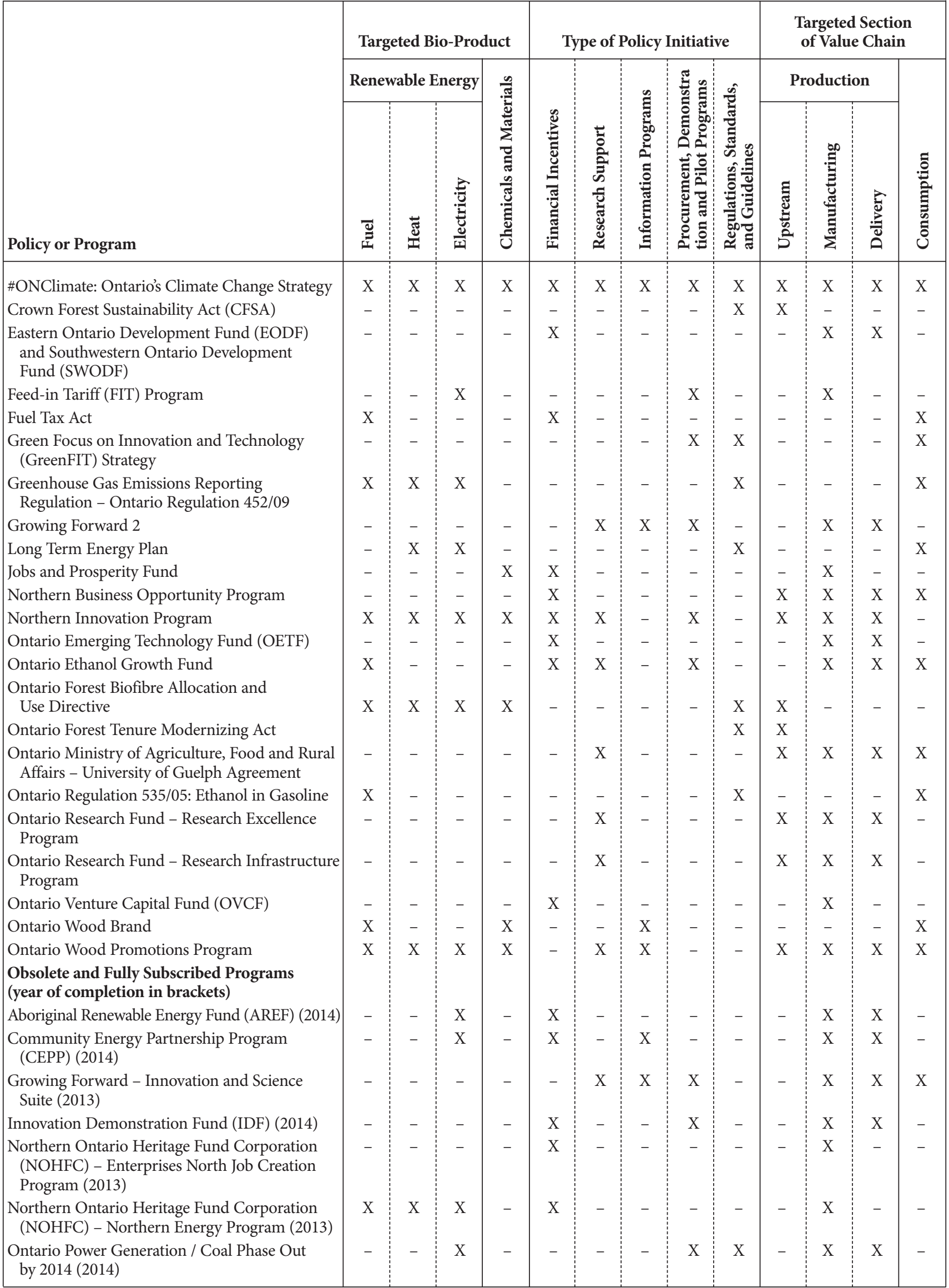




\begin{tabular}{|c|c|c|c|c|c|c|c|c|c|c|c|c|c|}
\hline \multirow[b]{3}{*}{ Policy or Program } & \multicolumn{4}{|c|}{ Targeted Bio-Product } & \multicolumn{5}{|c|}{ Type of Policy Initiative } & \multicolumn{4}{|c|}{$\begin{array}{l}\text { Targeted Section } \\
\text { of Value Chain }\end{array}$} \\
\hline & \multicolumn{3}{|c|}{ Renewable Energy } & \multirow{2}{*}{ 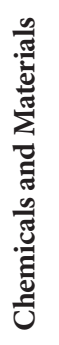 } & \multirow[b]{2}{*}{ 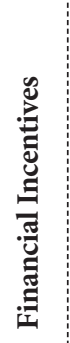 } & \multirow[b]{2}{*}{ 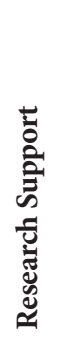 } & \multirow{2}{*}{ 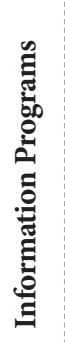 } & \multirow{2}{*}{ 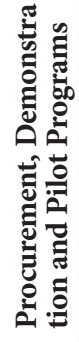 } & \multirow{2}{*}{ 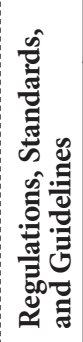 } & \multicolumn{3}{|c|}{ Production } & \multirow[b]{2}{*}{ 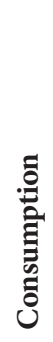 } \\
\hline & 丞 & 营 & 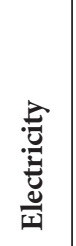 & & & & & & & 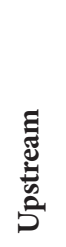 & 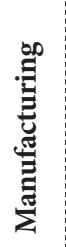 & 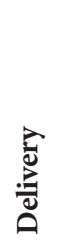 & \\
\hline Accelerated Capital Cost Allowance & $\mathrm{X}$ & $\mathrm{X}$ & $\mathrm{X}$ & - & $\mathrm{X}$ & - & - & - & - & $\mathrm{X}$ & $\mathrm{X}$ & $\mathrm{X}$ & $\mathrm{X}$ \\
\hline $\begin{array}{l}\text { Bioenergy Systems For Viable Stationary } \\
\text { Applications }\end{array}$ & $\mathrm{X}$ & $\mathrm{X}$ & $\mathrm{X}$ & - & - & $\mathrm{X}$ & $\mathrm{X}$ & $\mathrm{X}$ & - & - & $\mathrm{X}$ & - & $\mathrm{X}$ \\
\hline Build in Canada Innovation Program (BCIP) & $\mathrm{X}$ & $\mathrm{X}$ & $\mathrm{X}$ & $\mathrm{X}$ & - & $\mathrm{X}$ & - & $\mathrm{X}$ & - & - & $\mathrm{X}$ & $\mathrm{X}$ & - \\
\hline EcoEnergy for Biofuels & $\mathrm{X}$ & - & - & - & $\mathrm{X}$ & - & - & - & - & - & - & - & $\mathrm{X}$ \\
\hline Expanding Market Opportunities Program & - & - & - & $\mathrm{X}$ & - & $\mathrm{X}$ & $\mathrm{X}$ & - & $\mathrm{X}$ & - & - & $\mathrm{X}$ & $\mathrm{X}$ \\
\hline Gas Tax Fund & - & - & - & - & $\mathrm{X}$ & - & - & - & - & - & $\mathrm{X}$ & $\mathrm{X}$ & - \\
\hline Green Municipal Fund (GMF) & - & - & - & - & $\mathrm{X}$ & - & - & - & - & - & $\mathrm{X}$ & - & - \\
\hline Growing Forward 2-AgriInnovation Program & - & - & - & $\mathrm{X}$ & - & $\mathrm{X}$ & $\mathrm{X}$ & $\mathrm{X}$ & - & - & $\mathrm{X}$ & $\mathrm{x}$ & $\mathrm{X}$ \\
\hline Investing in Business Innovation & - & - & - & - & $\mathrm{X}$ & $\mathrm{X}$ & - & $\mathrm{X}$ & - & - & $\mathrm{X}$ & $\mathrm{X}$ & - \\
\hline $\begin{array}{l}\text { Investments in Forest Industry Transformation } \\
\text { (IFIT) }\end{array}$ & $\mathrm{X}$ & $\mathrm{X}$ & $\mathrm{X}$ & $\mathrm{X}$ & $\mathrm{X}$ & - & - & $\mathrm{X}$ & - & - & $\mathrm{x}$ & - & - \\
\hline $\begin{array}{l}\text { National Research Council of Canada Industrial } \\
\text { Research Assistance Program (NRC-IRAP) }\end{array}$ & - & - & - & - & $\mathrm{X}$ & $\mathrm{X}$ & - & - & - & $\mathrm{X}$ & $\mathrm{X}$ & $\mathrm{X}$ & $\mathrm{X}$ \\
\hline Northern Ontario Development Program (NODP) & - & - & - & - & $\mathrm{X}$ & - & - & - & - & - & $\mathrm{X}$ & $\mathrm{X}$ & - \\
\hline Renewable Fuels Standard & $\mathrm{X}$ & - & - & - & - & - & - & - & $\mathrm{X}$ & - & - & - & $\mathrm{X}$ \\
\hline $\begin{array}{l}\text { Scientific Research Experimental Development } \\
\text { (SR\&ED) Tax Incentive Program }\end{array}$ & - & - & - & - & $\mathrm{X}$ & $\mathrm{X}$ & - & - & - & - & $\mathrm{X}$ & $\mathrm{X}$ & - \\
\hline SD Tech Fund & - & - & - & - & $\mathrm{X}$ & - & - & $\mathrm{X}$ & - & - & $\mathrm{X}$ & - & - \\
\hline Transformative Technologies Program & $\mathrm{X}$ & - & - & $\mathrm{X}$ & - & $\mathrm{X}$ & - & $\mathrm{X}$ & - & $\mathrm{X}$ & $\mathrm{X}$ & - & - \\
\hline $\begin{array}{l}\text { Obsolete and Fully Subscribed Programs } \\
\text { (year of completion in brackets) }\end{array}$ & & & & & & & & & & & & & \\
\hline Agricultural Innovation Program (AIP)(2013) & - & - & - & - & $\mathrm{X}$ & $\mathrm{X}$ & - & $\mathrm{X}$ & - & $\mathrm{X}$ & $\mathrm{X}$ & $\mathrm{x}$ & - \\
\hline Agricultural Processing Initiative (API) (2014) & - & - & - & - & $\mathrm{X}$ & - & - & - & - & - & $\mathrm{X}$ & - & - \\
\hline Green Infrastructure Fund (GIF) (2014) & - & - & $\mathrm{X}$ & - & $\mathrm{X}$ & - & - & - & - & - & $\mathrm{X}$ & $\mathrm{X}$ & - \\
\hline Growing Forward 2 & - & - & - & - & - & $\mathrm{X}$ & $\mathrm{X}$ & $\mathrm{X}$ & - & - & $\mathrm{X}$ & $\mathrm{X}$ & $\mathrm{X}$ \\
\hline NextGen Biofuels Fund & $\mathrm{X}$ & - & - & - & $\mathrm{X}$ & - & - & $\mathrm{X}$ & - & - & $\mathrm{X}$ & - & - \\
\hline $\begin{array}{l}\text { Pulp and Paper Green Transformation Program } \\
\text { (2012) }\end{array}$ & - & $\mathrm{X}$ & $\mathrm{X}$ & - & $\mathrm{X}$ & - & - & - & - & $\mathrm{X}$ & - & - & - \\
\hline
\end{tabular}

(Ontario wood pellet example 2013 and 2020; (MNRF unpublished, van Loo and Koppejan 2008). Despite these opportunities, Ontario could still learn much from other jurisdictions that have successfully utilized targeted policies and programs which expand the use of biomass heat (Campbell et. al. 2014).

Support for biomass heat is prevalent in Northern European countries: Finland is a world leader in combined heat and power (CHP) that uses biomass as fuel (due in part to a simplified regulatory climate), and Sweden taxes fossil fuels so heavily that biomass is a relatively inexpensive fuel for heating. Under the broad umbrella of bioenergy policies, the focus in Ontario and Canada has been on renewable electricity and biofuel production with very few policies and pro- grams targeting biomass-based heat production. However, support for biomass heat is growing at the federal level with cumulative expansions of biomass-related applications of the Accelerated Capital Cost Allowance (ACCA) program and the National Research Council of Canada's program Bioenergy Systems for Viable Stationary Applications. Ontario's Climate Change Action Plan also indicates the province's ambition to work with the federal government to further expand the accelerated capital cost allowance program for technologies that reduce GHG pollution.

Bioenergy has been identified as the first step in building the biorefinery concept-a multi-output system that derives maximum benefit from the bio-based feedstock it uses (Stuart 2006, Chambost et al. 2008, Browne 2011). Therefore, 
high value-added bioproduct sectors are partly dependent on a thriving bioenergy sector because they can take advantage of economies of scale resulting from the production of biofuels. (Stuart 2006, Janssen et al. 2008, PwC 2011). Moreover, the development of a high-value bioproduct sector can leverage relationships, create linkages, and establish partnerships with upstream and downstream players along the bioproduct value chain. Jurisdictions with more mature bioeconomies have more policies focused on biochemicals and biomaterials, such as Finland's Advanced Cellulose to Novel Product program which promotes the use of cellulosic bioproducts. By comparison, Ontario has fewer incentive programs that target biochemicals and biomaterials, as almost all of the programs are heavily skewed towards bioenergy. The Investment in Forest Industry Transformation program is an exception, because it divides its funding support across bioproduct types.

\section{Types of policy initiatives}

As illustrated in Tables 2 and 3, the development of policy initiatives is not evenly distributed over the five types: Financial Incentives; Research Support; Information Programs; Procurement, Demonstration and Pilot Programs; and Regulations, Standards, and Guidelines. There is, however, some degree of overlap; most of the provincial policies and programs analyzed are designed to utilize multiple types of policy initiatives. The Ontario Ethanol Growth Fund is one such example of a program that administers multiple types of policy initiatives (e.g., financial incentive, research support and procurement, demonstration and pilot).

In Ontario and Canada, financial incentives are the dominant policy initiative, as evidenced by Tables 2 and 3. One way in which companies in emerging industries are made more attractive to the private sector for capital investment is through government incentives and grants (PwC 2010, World Bank 2011, Wydra 2012). Governments around the world have been investing extensively in the bioproduct industry, which reduces the need for financial investment from non-government sources and increases the potential for success of the company by reducing the risk involved in investing. These types of programs also exist in the EU, including Germany's Renewable Energy Sources Act, and Market Rebate Programme for Renewable Energy (Nast 2010), as well as the Finnish agency Sitra, which invests in innovative start-ups and venture capital funds in order to promote sustainable industries. In Ontario, the Ontario Venture Capital Fund is a joint government-private investor initiative to support innovative companies, but there is no specific bioeconomy investment focus.

Despite the existence of policies, programs and non-profit partners (see Appendix B) working to support bioproduct R\&D in Canada, in absolute terms, biotechnological investment in Canada is less than $1 \%$ of that in the United States (Industry Report 2010). In EU countries, supporting innovation and R\&D activities in the bioproduct sector is a commitment that is well-supported and coordinated through policy. In Germany, the Biomass Research Centre supports the effective integration of biomass as a valuable resource for a sustainable energy supply in the context of applied scientific research, including technical, environmental, economic, social, and energy issues. Likewise in Finland, Tekes, the Finnish Funding Agency for Technology and Innovation, is the main public funding organization for research, development and innovation. Sweden also has a central Swedish Innovation Agency, Vinnova, which annually funds $\$ 400$ million (CAD) of programs to foster sustainable growth. In contrast, both Ontario and Canada lack R\&D collaboration when compared to the $\mathrm{EU}$ jurisdictions because there is no central innovation agency at either a federal or provincial level (PwC 2011). When research paths are jointly determined between all stakeholders (i.e., industry, academia and government), this benefits the bioproduct sector by facilitating linkages in a fragmented and disparate value chain. Successful funding models in Northern Europe also help to encourage the commercial applicability of R\&D efforts and technology diffusion and transfer.

This is not to say that Ontario has not supported collaborative efforts to increase innovation in the bioeconomy. In 2008, the Ontario government established the Centre for Research and Innovation in the Bioeconomy (CRIBE) to help transform the forest industry and to move the province to the forefront of the commercialization of the forest products industry (OMRI 2010). Some of CRIBE's investment projects have included wood to fuels, wood composites, biochemicals, bioenergy systems, biomass heat, research innovation, and lignin extraction. Like other successful collaborative innovators, CRIBE has leveraged partnerships with various academic institutions such as Lakehead University, which allows CRIBE to build on the university's pre-existing research strengths. CRIBE has also initiated a long-term partnership with FPInnovations to establish research capacity in northern Ontario.

At the national level, the launch of the federal Strategic Partnership Initiative (SPI) in 2010 sought to encourage coordination among government ministries/agencies across the country. The program provides access to funding from federal departments, provincial and territorial governments, and the private sector in an effort to promote economic development in Aboriginal communities within several key sectors, including forestry and energy. For example, under SPI, the Aboriginal Forestry Initiative received a total of \$3.95 million between 2010 and 2013 to support sustainable forestry activities for Aboriginal communities across Canada.

FPInnovations is an example of an effective public-private partnership at the federal level. It is Canada's leading forest products research institute and performs research, technical services and technology transfer activities relating to wood harvesting, wood products, pulp and paper, nanotechnology, bio-energy, and chemical production. As part of the Transformative Technology research program sponsored by Natural Resources Canada (NRCan), FPInnovations developed a technology that resulted in the establishment of a pilot-scale lignin extraction plant to provide commercial-quality samples to potential end-users for product development and testing. The Forest Products Association of Canada (FPAC), along with FPInnovations and NRCan, collaborated on the "Bio-Pathways" project which examined the global market potential of emerging bioenergy, biochemicals and bioproducts, and which explored new approaches to managing value and building partnerships in this critical area. FPInnovations is positioned to take a greater leadership role in these areas, which may help accelerate the development of the bioeconomy across Canada (refer to Appendix B). 
As illustrated in Tables 2 and 3, the following two types of policy initiatives have not been widely utilized to support the forest bioeconomy in Ontario: information programs; and, regulations, standards and guidelines. While industry member organizations outlined in Appendix B do attempt to administer some information programs, these resources are mainly directed to sustainability initiatives and traditional products, and are not focused on the forest bioeconomy. An exception to this trend is the Ontario Wood program, an information program that encourages Ontarians to understand the benefits of using locally-sourced wood products and works to raise awareness of the sustainable forest management practices in the province. By offering promotional material such as stickers and tags, Ontario Wood helps producers differentiate their local bio-based products from conventional competing options.

Both the EU and the US have put forth significant effort to create a market for bioproducts through regulations, including setting mandates and targets. These mandates provide detailed roadmaps of how states mean to reach the targets they set on renewable energy usage. For example, in 2010, all EU member states submitted national renewable energy action plans that outline how each member state expects to reach its legally binding 2020 target for the proportion of renewable energy in its final energy consumption. The government of Sweden has decided that by 2020, renewable energy will represent at least $50 \%$ of the total energy usage, with at least $10 \%$ in the transport sector. Finland has more ambitious goals, aiming to have a $20 \%$ share of biofuel in transport fuels. In addition, they aim for a 25 TWh target for the use of wood chips in heat and power generation by 2020 . In Ontario, less ambitious goals are set: a mandate has been established that requires gasoline to contain 5\% ethanol, and in 2014 it was mandated that diesel contain at least $2 \%$ biofuel, with that proportion climbing to $4 \%$ by 2017. According to Ontario's Climate Change Action Plan (MOECC 2016), the province intends to set a Renewable Fuels Standard to increase the percentage of renewable content required in gasoline sold across Ontario in order to achieve a 5\% reduction in GHG emissions from gasoline by 2020. Nationwide, Canada has implemented the 5\% ethanol and 2\% biodiesel renewable fuel standard since 2011, but neither of these initiatives is targeted specifically toward forest-based biofuels. Many of the EU and US mandates are more aggressive and have a longer history than those in Canada.

Increasing global concern over climate change is placing greater emphasis on transitioning to bio-based alternatives, and regulatory measures are the most common way to facilitate this transition. Lowering GHG emissions by $20 \%$ from 1990 levels is a target set under the Europe 2020 growth strategy. ${ }^{5}$ The federal government in Canada has committed to decreasing GHG emissions to 30\% below 2005 levels by 2030 . At the subnational level, British Columbia adopted a carbon tax in 2008 and is developing a cap-and-trade program. Quebec, in partnership with California, has adopted a regulatory cap-and-trade system for GHG emission allowances that is based on the design established by the Western Climate Ini-

\footnotetext{
${ }^{5}$ http://ec.europa.eu/eu2020/pdf/COMPLET\%20EN\%20BARROSO \%20\%20\%20007\%20-\%20Europe\%202020\%20-\%20EN\%20version.pdf
}

tiative (WCI). ${ }^{6}$ On May 19, 2016, Ontario finalized its rules for cap-and-trade, which took effect July 1, 2016. These are examples of market-based regulatory initiatives that promote the bioeconomy as a means to reduce greenhouse gas emissions and they could serve to place emerging bioproduct alternatives in a cost-competitive position with traditional fossil fuel-based products. Though the Canadian federal government is also exploring ways to deal with climate change, the final outcome regarding federal GHG regulations and tools for meeting compliance obligations remain unclear. Nonetheless, developing the bioeconomy is identified as a key element for tackling climate change issues and for the advancement of smart and green growth.

\section{Value chain}

A comparison of Tables 2 and 3 demonstrates that both levels of government utilize similar policy and program tools to promote the bioeconomy. A look at the distribution of policies across the value chain indicates that both Ontario and Canada target the production of bioproducts more than the consumption of bioproducts. Ontario and Canada tend to focus specifically on supporting R\&D for manufacturing, as opposed to targeting the end-use segment of the value chain through policies such as consumption targets. As a result, the bulk of Ontario's and Canada's policies provide financial incentives and R\&D for the manufacturing and delivery of bioproducts. In contrast, in multiple EU jurisdictions, policy instruments promote the consumption of bioproducts through public procurement measures and support of private demand (Wydra 2012).

The R\&D funding mechanisms apparent in mature bioeconomies encourage collaboration among industry, academic institutions and government, and help ensure commercial outcomes. Increased coordination of $\mathrm{R} \& \mathrm{D}$ activities among the several government ministries, agencies and other government-related organizations providing $R \& D$ funding can increase the effectiveness of R\&D. Another way to facilitate linkages and partnerships across the bioproduct value chain is through the formation of clusters. The clustering of companies that complement each other within the same industry promotes innovation and the competitiveness of individual firms, which stimulates economic growth across the region (PwC 2010). Clustering is a key success factor in the development of viable bioproduct companies (Benjamin et al. 2009, Finnish Cluster Research Strategy 2010) and the economic development of forest-dependent communities (Albert 2007). Cluster development, especially in technological fields, requires significant government funding and a focused cluster strategy which also leverages public-private partnerships. In some jurisdictions, such as Germany, the development of clusters is explicitly encouraged. German policy in this area encourages the development of technology clusters via the Leading-Edge Cluster Competition, which is a component of the country's High-Tech Strategy. Collaborative models,

\footnotetext{
${ }^{6}$ The WCI (http://www.westernclimateinitiative.org) is a collaboration of independent jurisdictions working together to identify, evaluate, and implement emissions trading policies to tackle climate change at a regional level. The WCI partners include members from California and the four Canadian provinces of British Columbia, Ontario, Quebec and Manitoba.
} 
which are often found in European countries, encourage partnership and linkage throughout the value chain, and increase the likelihood of successful innovation. An additional factor is geographic proximity; it not only enhances the economics of the development and production of bioproducts, but also improves collaboration across the bioproduct value chain. Canadian geography is significantly different from that of EU member states and the broad distribution of forest industry assets and infrastructure throughout rural and Northern communities has been cited as a potential barrier to the establishment of a cluster approach that could mimic the successes found in Northern European countries (PwC 2011).

\section{Conclusions}

At its peak, Ontario's forestry sector contributed $\$ 19$ billion worth of business in the province and supported over 200000 direct and indirect jobs across 260 Ontario communities. ${ }^{7}$ While employment and GDP contributions from the sector are smaller now, the emerging bioeconomy represents a clear opportunity for the forest industry to innovate and regain its preeminent position among Ontario's industrial sectors. Key to increasing the effectiveness and efficiency of policy support for the emerging bioeconomy is to improve coordination among government ministries/agencies that play a supporting role in the bioproducts sector. The establishment of a strategic bioeconomy vision for Ontario that provides a clear roadmap for the future of the bioproducts industry is critical. A core principle of this vision should be to encourage collaboration among government ministries, agencies, and other organizations that play a role in the forest bioproduct industry in Ontario.

This policy review identified that electricity and fuels are the bioproducts receiving the most policy support in Ontario. Since Ontario's cap-and-trade policy took effect in July 2016, bioenergy is increasingly becoming a major focus of many government initiatives. There is also, however, opportunity under this new climate regime for expanded policies which lend support to biomass heat, cellulosic fuels, biochemicals, and biomaterials development. Ultimately, for Ontario's bioeconomy to mature and participate in growing markets for high-value biochemical and biomaterials, the province's policy focus will need to shift to include more bioproduct types.

Most of the policies supporting the forest bioeconomy in Ontario entail some manner of direct or indirect financial incentive. Ontario also provides considerable support for research, procurement, demonstration and pilot activities relevant to the bioproduct sector. The increased coordination of these activities through cluster creation policy or a centralized, innovation-focused body can help boost the effectiveness of R\&D and better ensure commercial outcomes. Wellplanned complementary policies utilizing multiple types of policy tools, including information programs and regulatory regimes, are crucial to eventual success. Bioeconomy information programs have been utilized successfully by other jurisdictions, and increased enthusiasm for this type of policy initiative presents opportunity for Ontario's government and

\footnotetext{
${ }^{7}$ http://www.ofia.com/growing_trees/economics.html
}

industry to support this emerging sector. Acting on such opportunities and focusing on regional strengths will ensure that the benefits of economic growth are coupled with environmental sustainability.

Effective policy development also needs to represent all aspects of the bioeconomy along each aspect of the value chain, including: development of new technologies, up-scaling of pilot-level technologies and their commercialization, supply of raw material (wood fibre), manufacturing, attracting capital investment, and infrastructural support for market establishment (Kant and Wang 2012). Most of the existing policies that impact the forest bioeconomy in Ontario are targeted at production and manufacturing. There is opportunity for new policy development to look at supporting the upstream and consumption aspects of the value chain.

Ontario has the opportunity to create a thriving and sustainable bioeconomy that will confer environmental, social, and economic benefits upon the province and will reduce the province's dependence on fossil fuels. Key to the success of the forest bioeconomy in Ontario is to bring the abundant forest resources and emerging technologies together in a manner that complements the province's existing manufacturing infrastructure, forest operations sector, public policies, and social values. All of these pieces must come together in the right way for the entire bioeconomy "puzzle" to be complete. As demonstrated by examples discussed in other successful jurisdictions, difficult, ambitious, and strategic decisions are required to overcome the challenges that lie in the path towards the development of a vibrant forest bioeconomy in Ontario.

\section{References}

Albert, S. 2007. Transition to a Forest Bio-economy: A Community Development Strategy Discussion. J. Rural Commun. Develop. 2: 64-83.

Becker, D.R., D. Larson and E.C. Lowell. 2009. Financial considerations of policy options to enhance biomass utilization for reducing wildfire hazards. Forest Policy Econ. 11: 628-635.

Becker, D.R., C. Moseley and C. Lee. 2011. A supply chain analysis framework for assessing state-level forest biomass utilization policies in the United States. Biomass Bioenerg 35: 1429-1439.

Benjamin, J., R.J. Lilieholm and D. Damery. 2009. Challenges and Opportunities for the Northeastern Forest Bioindustry. J. Forest. 107(3): 125-131.

Browne, T. 2011. Economics of commodity chemicals and fuels from forest biomass: The biorefinery option. J. Sci. Technol. Forest Prod. Processes 1(1): 42-45.

Bug, T. 2010. German investments in industrial biotechnology. Ind. Biotechnol. 6(5): 241-243.

Campbell, K.A., S. Banducci, N. Hughes and I. Majumdar. 2014. Biomass Heat What's in it for Ontario? Ontario Ministry of Natural Resources, unpublished internal discussion paper.

Chambost, V., J. Mcnutt and P.R. Stuart. 2008. Guided tour: Implementing the forest biorefinery (FBR) at existing pulp and paper mills. Pulp Paper Can. 109(7): 1-9.

Cockburn, I.M., and S. Stern. 2010. Finding the endless frontier: Lessons from the life science innovation system for technology policy. Capitalism and Society, 5(1): 1-48

Cooke, P. 2007. Growth cultures: The global bioeconomy and its bioregions. London: Routledge.

Cooper, D. 2007. The Effectiveness of Policy Instruments in Promoting Bioenergy. Tyndall Centre, University of Manchester. 
Dymond, C.C., B.D. Titus, G. Stinson and W.A. Kurz. 2010. Future quantities and spatial distribution of harvesting residue and dead wood from natural disturbances in Canada. Forest Ecol. Manag. 260(2): 181-192.

European Commission. 2012. Innovating for Sustainable Growth: A Bioeconomy for Europe. European Economic and Social Committee. Brussels, Belgium. http://ec.europa.eu/research/bioeconomy/pdf/official-strategy_en.pdf last accessed June 24, 2016.

Finnish Cluster Research Strategy 2010. The world's leading forest cluster 2030. $24 \mathrm{p}$.

FPAC (Forests Products Association of Canada). 2011. The New Face of the Canadian Forest Industry: The Emerging Bio-revolution: The Bio Pathways Project. 12 p. http://www.fpac.ca/publications/ BIOPATHWAYS\%20II\%20web.pdf last accessed September 17, 2014. FPAC (Forests Products Association of Canada). 2012. Vision 2020 - Canada's Natural Advantage. http://www.fpac.ca/index.php/ en/vision2020/ last accessed September 17, 2014.

Gobina, E. 2014. Biorefinery Products: Global Markets. BCC Research. http://www.bccresearch.com/market-research/energyand-resources/biorefinery-products-market-egy117a.html last accessed June 2016.

Hermann, B., M. Carus, M. Patel and K. Blok. 2011. Policy, Regulation and Certification: Current policies affecting the market penetration of biomaterials. Biofuel. Bioprod. Bior. 5(6): 708-719.

IISD. 2012. (International Institute of Sustainable Development. 2012). State of Play on Biofuel Subsidies: Are policies ready to shift? http://www.iisd.org/gsi/sites/default/files/bf_stateplay_2012.pdf last accessed September 17, 2014.

Industry Report. 2010. Canada's bioeconomy: Strengths, resources \& future directions. Ind. Biotechnol. 6(1): 27-33.

Janssen, M., V. Chambost and P.R. Stuart. 2008. Successful partnerships for the forest biorefinery. Ind. Biotechnol. 4(4): 352-362.

Kant and Wang. 2012. An Economic Analysis of Public Policies Supporting the Forest-based Bioproduct Sector in Ontario and other Jurisdictions. Kant \& Wang Consultants. Final Report Submitted to the Ontario Ministry of Natural Resources.

Levin, R., S. Krigstin and S. Wetzel. 2011. Biomass availability in eastern Ontario for bioenergy and wood pellet initiatives. Forest. Chron. 87(1): 33-41.

Nast, M. 2010. Renewable energies heat act and government grants in Germany. Renew. Energ. 35(8): 1852-1856

OEE. 2014a. (Office of Energy Efficiency. 2014a). Comprehensive Energy Use Database Table, Residential Sector, Ontario. Natural Resources Canada, Ottawa, ON. http://oee.nrcan.gc.ca/corporate/ statistics/neud/dpa/showTable.cfm?type $=\mathrm{CP} \&$ sector $=$ res\&juris $=$ on $\& \mathrm{rn}=2$ \&page $=4 \& \mathrm{CFID}=31712387 \& \mathrm{CFTOKEN}=802812 \mathrm{c} 5883 \mathrm{~d} 53 \mathrm{a}$ f-ED32B485-DC4B-3E4D-262F9F77B28766E3

OEE. 2014b. (Office of Energy Efficiency. 2014b). Comprehensive Energy Use Database Table, Commercial/Institutional Sector, Ontario. Natural Resources Canada, Ottawa, ON. http://oee.nrcan. gc.ca/corporate/statistics/neud/dpa/showTable.cfm?type=CP\&sector $=$ com \& juris $=$ on $\& \mathrm{rn}=2 \&$ page $=4 \& \mathrm{CFID}=31712387 \& \mathrm{CFTOKEN}=$ 802812c5883d53af- ED32B485-DC4B-3E4D-262F9F77B28766E3 MOECC. 2016. (Ontario Ministry of Environment and Climate Change. 2016). Ontario's Five-Year Climate Change Action Plan 2016-2020. Toronto, ON http://www.applications.ene.gov.on.ca/ ccap/products/CCAP_ENGLISH.pdf last accessed June 15, 2016.
OMRI. 2010. (Ontario Ministry of Research and Innovation. 2010). An analysis of the convergence of technology, policy and capital in Ontario. Final report submitted to Ontario Ministry of Research and Innovation. http://www.investtoronto.ca/InvestAssets/ PDF/Reports/MRI-asset-maps.pdf last accessed September 17, 2014. OECD. 2009. (Organization for Economic Co-operation and Development. 2009). The Bioeconomy to 2030: Designing a Policy Agenda. OECD Publishing doi: 10.1787/9789264056886-en

Pembina Institute 2005. A Scoping Study on Federal Policies for Creating Market Demand for Bio-products in Canada. Industry Canada Report: Market Development for Bio-products. 44 p.

Porter, M.E. 1990. The Competitive Advantage of Nations. Harvard Business Review. March - April. 73-91.

Puddister, D., S.W.J. Dominy, J.A. Baker, D.M. Morris, J. Maure, J.A. Rice, T.A. Jones, I. Majumdar, P.W. Hazlett, B.D. Titus, R.L. Fleming and S. Wetzel. 2011. Opportunities and challenges for Ontario's forest bioeconomy. Forest. Chron. 87(4): 468-477.

PwC. 2010. (PricewaterhouseCoopers. 2010). Government's Many Roles in Fostering Innovation. 66 p.

PwC. 2011. (PricewaterhouseCoopers. 2011). Competitiveness of Ontario's Forest Bioproduct Industry. Final Report Submitted to the Ontario Ministry of Northern Development, Mines, and Forestry.

Samson, R., S. Bailey, J. Dooper, S. Mulder, T. Ingram, K. Clark and C. Ho Lem. 2008. Analysing Ontario biofuel options: greenhouse gas mitigation efficiency and costs. BIOCAP Canada Foundation - prepared by Resource Efficient Agricultural Production (REAP), Canada. http://www.reap-canada.com/online_library/ ghg_offsets_policy/BIOCAP_REAP_bioenergy_policy_incentives 08Jan18-Final.pdf last accessed September 17, 2014.

Sorda, G., M. Banse and C. Kemfert. 2010. An overview of biofuel policies across the world. Energy Policy 38: 6977-6988.

Sparling, D., E. Cheney and J. Cranfield. 2011. Not enough green in Canada's bioproduct industry. Report from the Richard Ivey School of Business, University of Western Ontario. $30 \mathrm{p}$. http://sites.ivey.ca/agri-food/files/2009/09/Sparling-Cheney-Cranfield-Bioproduct-Report.pdf last accessed on September 17, 2014.

Stuart, P.R. 2006. The forest biorefinery: survival strategy or Canada's P\&P sector? Pulp Paper Can. 107(6): 13-16.

van Loo, S. and Koppejan, J. 2008. The Handbook of Biomass Combustion and Co-firing. Taylor \& Francis. 442 p.

Wydra, S. 2012. Overview of Policy Measures for Biobased Products. Ind. Biotechnol. 8(1): 8-12.

World Bank Report 2011. Igniting Innovation: Rethinking the Role of Government in Emerging Europe and Central Asia. Bringing innovations to market - boosting private incentives through public instruments. Chapter 4 pp 123-156. http://siteresources.worldbank.org/INTECA/Resources/257896-1314820419212/ chapter4.pdf last accessed on September 17, 2014.

\section{APPENDICES}

Associated appendices for this policy discussion are accessible from the Canadian Institute of Forestry's Web site: http://www.cif-ifc.org/wp-content/uploads/2014/05/Bioeconomy-Policy-Paper-Appendices.pdf 